\title{
The Role of Information Communication Technology (ICT) in Combating Corrupt Business Activities in Nigeria
}

\author{
Dr. Bello Ayuba ${ }^{1}$, Ibrahim Ali Aliyu ${ }^{2}$ \\ ${ }^{1}$ (Department of Business Administration, University of Abuja, Gwagwalada-Nigeria). \\ ${ }^{2}$ (Consultant, Education Watch Today Ltd, Gwagwalada, Abuja, FCT-Nigeria).
}

\begin{abstract}
This study examines the role of Information Communication Technology (ICT) in combating corrupt business activities in Nigeria. The main objective is to investigate how adoption of ICT helps in reducing the menace of corrupt practices in business activities in Nigeria. As part of the methodology, a sample of 200 respondents, representing 70 percent of the population (285) was used for analysis in the study. The analysis was conducted using Descriptive Statistics and chi-square to test the formulated hypotheses which reveal that ICT helps in reducing organizations spending \& increased earning, identification of ghost workers and elimination of corrupt practices of following files and cheques, as well as enhancing marketing practice and tracking of financial fraudsters and other fraudulent banking services which significantly helped in achieving greater transparency, accountability and effective management and reduce opportunities for corruption. Some recommendations were made, among the major recommendations is the need for business organizations (public and private) in Nigeria to ensure adequate provision of ICT infrastructure such as access to computers and capacity to connect to the internet globally and the need to ensure massive involvement of local communities in the ICT derive in the country
\end{abstract}

Key Words: Business Activities, Corruption, E-governance, Information Communication Technology (ICT) and Nigeria.

\section{Introduction}

The potential for ICT to transform business activities has been heralded at various points throughout the past half-century. Even by the 1960s and the 1970s, when computers started to appear in business and governmental organizations, some business practitioners predicted that information technology would revolutionalize business activities in the country. As increasingly sophisticated information and communication technologies (ICTs) spread across all organizations during the 1980s and 1990s, politicians jostled to claim credit for the country's information age (Danfulani, 2003). By the beginning of the twenty-first century, the use of internet became increasingly widespread; claims for the transformative power of ICTs became correspondingly enthusiastic (Margetts, 2005).

The advent of Information Communication Technology (ICT) has ushered in new ways of doing things in almost all spheres of life (Gasco, 2003). The business environment is not left out in this Information Technology derive as it is by far the most important and impressive means by which business organizations remain competitive in the dynamic environment (Kotler, 2003). It plays significant role in every aspect of organizations survival particularly, Employees, Banking, Government Businesses etc. There is no contesting the fact that introduction of ICT have massively downsized the level of corrupt business activities in the country, the indices have shown that there is remarkable improvement in the cleansing processes in the system (Danfulani, 2013). Local and international anti graft watch dogs gave introduction of ICT through e-governance much of the credit in the fight against corruption in Nigeria (Adewale, 2011).

It is in recognition of the importance of ICT in combating corrupt business activities that this study was conducted to examine how ICT adoption helps in reducing the menace of corrupt practices associated with business activities in Nigeria. For a long time now, corruption has eaten deep into all spheres of life in the Nigerian society and previous effort by other researchers to investigate the role of ICT in combating corruption in business activities in Nigeria has remained under studied (Monday, 2013) which this study is designed to accomplish. The work therefore, studied the perceived benefits associated with ICT adoption in both public and private sector organizations in Nigeria for effective and efficient performance.

\subsection{Objectives of the Study}

The main objective of the study is to investigate how adoption of ICT helps in reducing the menace of corrupt practices in business activities in Nigeria. The specific objectives include; (2) to assess how ICT adoption helps in reducing corrupt practices associated with selection and training of employees in Nigeria; (3) to ascertain how ICT adoption enhances transparency and accountability in business of governance in Nigeria; (4) to identify how ICT impact on marketing practice in Nigeria; (5) to investigate how ICT helps in combating 
fraudulent Banking services in Nigeria and (6) to examine how ICT enhances effective payment of corporate taxes in Nigeria.

\subsection{Hypotheses Statement}

The following null-hypotheses shall be tested in this study;

Hypothesis One $\left(\mathrm{H}_{1}\right)$ : ICT adoption does not have significant impact on the reduction of corrupt practices in business activities in Nigeria.

Hypothesis Two $\left(\mathrm{H}_{2}\right)$ : ICT adoption increases corrupt practices associated with selection and training of employees in Nigeria.

Hypothesis Three $\left(\mathrm{H}_{3}\right)$ : ICT adoption does not enhance transparency and accountability in business of governance in Nigeria.

Hypothesis Four $\left(\mathrm{H}_{4}\right)$ : ICT adoption does not have significant impact on marketing practice in Nigeria

Hypothesis Five $\left(\mathrm{H}_{5}\right)$ : ICT adoption does not help in combating fraudulent banking services in Nigeria.

Hypothesis $\mathrm{Six}\left(\mathrm{H}_{6}\right)$ : ICT adoption does not enhance effective payment of corporate taxes in Nigeria.

\subsection{Meaning of Information and Communication Technologies (ICT)}

Bature (2007) defines Information and Communication Technologies as those technologies that provide access to information through telecommunications. It is information exchange which facilitates the way information flows faster, more generously, and less expensively throughout the planet for decision-making and for development (Ahmed, et al, 2006). It focuses primarily on communication technologies such as the Internet, wireless networks, cell phones and other communication mediums. In the past few decades, ICT have provided society with a vast array of new communication capabilities. For example, people can communicate in real-time with others in different countries using technologies such as instant e-messaging, video-conferencing, social networking websites like facebook and twitter which allow users from all over the world to remain in contact and communicate on regular basis. Modern ICT created a "global village", in which people can communicate with others across the world as if they were living next door.

\subsection{Issues and Challenges of ICT in Nigeria}

The World Bank classified Nigeria as low-patronage because of inadequate provision of ICT infrastructure such as access to computers and capacity to connect to internet (Idowu et al, 2003). For business activities to prosper in Nigeria, such infrastructure be readily made available. Nigeria as the largest country and giant of Africa is still faced with poverty and limited social development. If this trend should continue, the country may not be able to meet with the future ICT technological goals. Ahiakwo (2000) identifies some of the challenges as: (1) Inequality in global distribution of resources; (2) Inadequate education; (3) Corrupt Practices in governance; (4) Lack of conducive business environment; (5) Poor Economic Management; (6) Limited involvement of local communities; (7) Inadequate IT infrastructure; (8) Poor network service quality, and (9) Problem of equipment vandalism facing the industry which is growing daily as a result of crime and violence arising from insurgency and communal conflicts.

\subsection{Meaning of Corruption}

Ngouo (2000) defines corruption as the exploitation of public positions for private benefits. She further observed that the lack of any civil spirit among all categories of civil servants leads to corruption and misappropriation of public funds. Akindele (2005) sees corruption as a behavior, which deviates from the formal rules of governing the actions of someone in a position of authority while, Osunyinkanmi (2007), opines that the term corruption is synonymous to the terms Fraud, Bribery, Settlement etc. Adewale (2011) view corruption as an act of diverting the resources that should have been used for developmental purposes of the society to private or personal use.

\subsection{Business Activities}

Drucker (1973) described the term business as the social institutions by which economic efforts are organized. These social institutions are the arrangements devised to carry on major business activities such as production, marketing, accounting/financing, banking, managerial, and government businesses, as well as 
selection and training of employees and other activities that provide goods and services to people. Business activities involve any attempt organization carry out to earn a profit by providing goods or services that the society needs and wants (Kotler, 2003).

\subsection{The Role of ICT in Combating Corrupt Business Activities in Nigeria}

The explosive growth in Information Technology has had a major impact on the way organizations use ICT to combat corruption and bring value to both the organization and their customers. It has helped in nipping in the bud, the menace of corrupt practices and its resulting consequences on business activities in Nigeria (Ahmed et al, 2006). ICT plays significant role in e-governance, banking operations, marketing of goods and services and Selection and Training of Employees. Information and Communication Technologies (ICTs) have changed the process of governance in Nigeria. To manage government affairs for the benefits of citizens, governments have adopted e-governance technologies in service delivery. Thus, what is e-governance?

\subsection{E-Governance}

The term governance needs to be understood before we move on to e-governance. The concept of "governance" is as old as human civilization. In essence, the term "governance" refers to the process of decisionmaking and the process by which decisions are implemented (or not implemented). The word "governance" can be used in several contexts such as corporate governance, international governance, national governance and local governance. Governance is not the exclusive preserve of the government. It extends to civil society and the private sector. It covers every institution and organization from family to the state. The term e-governance has no single universal definition. The term was perhaps coined about a decade ago after the success of electronic commerce to represent a public sector equivalent of e-commerce. The definition of the concept of e-governance and its evolution in time has been the focus of a large body of research (Fang, 2002; Hu et al., 2009). More or less restrictive definitions of e-governance have been given, but there is still no unique definition of the term (Yildiz, 2004).

Nevertheless, e-governance has been described as the use of information technologies (such as the Internet, the World Wide Web, and mobile computing) by government agencies that can transform their relationship with citizens, businesses, different areas of government, and other governments. These technologies help deliver government services to citizens, improve interactions with businesses and industries, and provide access to information (Moon, 2002). The Department of Economic and Social Affairs of the United Nations also defines e-governance as utilizing the internet and the world-wide-web for delivering government information and services to citizens (United Nations, 2008). It involves the use of emerging information and communication technologies to facilitate the processes of government and both public and business administration (Kotler et al, 2006).

\subsection{Study Approach}

\section{Methodology}

This study adopted a survey approach with a population of 285 business organizations consisting of different types of organizations (public and privately owned). A sample of 200 respondents drawn from the six geo-political zones of the country, representing 70 percent of the total population was used in the study. The sample of the study analyzed using descriptive statistics anad chi-square was drawn in such a manner that it ensures accuracy and reliability of data and eliminates chances of bias in the selection process. The sampling is done in a way that every element of the population has an equal and independent chance of being included by allowing randomness to prevail in the selection process. The study focuses mainly on how ICT help in combating corruption in key business activities in Nigeria namely; government businesses (e-governance), marketing, accounting, Banking and Selection and Training of Employees of the studied organizations. A time period under review of 6 years, from 2008 to 2013, was chosen because it is believed that the scope provided enough insight into the present state of ICT adoption by most business organizations in Nigeria (Monday, 2013).

\subsection{Theoretical Bases for the Study}

In order to investigate the role of ICT in combating corrupt business activities in Nigeria, the researches reviewed here made use of a variety of theories, including the crowding-out effects theory of corruption in Nigeria (Adewale, 2011), e-governance theory (Danfulani, 2013; Margetts, 2005 \& Fatile, 2012) and theory on marketing management process (Kotler, 2003).

\section{Results and Discussions}

Descriptive statistics of frequencies and percentages were used to analyze the demographic characteristics of the respondents while the non-parametric statistics of chi-square was used to test the 
hypotheses in line with the objectives of the study. The decision criterion for the hypotheses tested was set at 0.05 percent level of significance.

\subsection{Response Rate}

Table 1 shows that out of the 215 questionnaires that were administered to employees of different types of organizations (both public and private) for the study, 200 were retrieved, constituting $93 \%$ response rates which were used for the analysis. Out of these, 35 of them representing $17.5 \%$ were employees in some federal and states of the federation in the six geo-political zones of the country. A larger percentage of the questionnaires, 75 or $37.5 \%$ were administered to some employees of Local Government Council's across the geo-political zones of the country, while from the private sector, 43 or $21.5 \%$ were administered to employees of selected manufacturing companies in the three industrial zones. In the same sector, 30 or $15 \%$ of the respondents were employees of some service companies quoted on the Nigerian stock exchange as at December, 2013, while other respondents such as non-governmental organizations, consultants, Individual business men etc constituted 17 which accounted for $8.5 \%$ of the total responses.

Table 1: Response Rate

\begin{tabular}{|c|c|c|c|c|c|}
\hline $\begin{array}{l}\text { Respondents: } \\
\text { Employees }\end{array}$ & Types of Organizations \& & Location & $\begin{array}{l}\text { Number of } \\
\text { Questionnaires } \\
\text { Administered }\end{array}$ & $\begin{array}{l}\text { Number of } \\
\text { Questionnaires } \\
\text { Retrieved }\end{array}$ & Percent \\
\hline \multirow[t]{2}{*}{ Public } & Federal \& State Civil Employees & $\begin{array}{l}\text { Six Geo-political } \\
\text { Zones }\end{array}$ & 40 & 35 & 17.5 \\
\hline & $\begin{array}{l}\text { Local Government Council } \\
\text { Employees }\end{array}$ & $\begin{array}{l}\text { Six Geo-political } \\
\text { Zones }\end{array}$ & 80 & 75 & 37.5 \\
\hline \multirow[t]{2}{*}{ Parivate } & Manufacturing companies & $\begin{array}{l}\text { Three Industrial } \\
\text { Zones }\end{array}$ & 45 & 43 & 21.5 \\
\hline & Service Companies & $\begin{array}{l}\text { Three Industrial } \\
\text { Zones }\end{array}$ & 32 & 30 & 15.0 \\
\hline \multirow[t]{2}{*}{$\begin{array}{l}\text { Public } \\
\text { Private }\end{array}$} & Others & $\begin{array}{l}\text { Six Geo-political } \\
\text { Zones }\end{array}$ & 18 & 17 & 8.5 \\
\hline & Total & & 215 & 200 & 100 \\
\hline
\end{tabular}

Source: Survey Data, 2013

\subsection{Demographic Characteristics of Respondents}

Since the characteristics of the respondents influence results, we therefore present the demographic data of the respondents in Table 2. As can be seen on the table, information on four (4) different characteristics of respondents that are relevant to the study were collected and interpreted. Information on respondents' age, gender, occupation and educational qualification were collected for use in the analysis. All the study variable scales are measured using a Likert scale rated varying from 1 to 5 (strongly disagree to strongly agree).

Table 2: Demographic Data of Respondents

\begin{tabular}{lllll}
\hline S/N & Characteristics & Respondents' Category & Frequency & Percent \\
1. & Age & $15-25$ years & 20 & 10.0 \\
& & $26-35$ years & 60 & 30.0 \\
& & $36-45$ years & 96 & 48.0 \\
& & $46-56$ years & 24 & 12.0 \\
& & Total & $\mathbf{2 0 0}$ & $\mathbf{1 0 0 . 0}$ \\
& & Female & 79 & 39.0 \\
& Gender & Male & 121 & 61.0 \\
& & Total & $\mathbf{2 0 0}$ & $\mathbf{1 0 0 . 0}$ \\
3. & Occupation & Local Council Employees & 35 & 17.5 \\
& & Manufacturing Companies & 75 & 37.5 \\
& & Service Companies & 43 & 21.5 \\
& & Others & 30 & 15.0 \\
& & Total & 17 & 8.5 \\
4. & Educational Qualification & $\mathbf{2 0 0}$ & $\mathbf{1 0 0 . 0}$ \\
& & Degree & 106 & 53.0 \\
& & Post-graduate & 52 & 26.0 \\
& & Diploma & 18 & 9.0 \\
& & Others & 24 & 12.0 \\
& & Total & $\mathbf{2 0 0}$ & $\mathbf{1 0 0 . 0}$ \\
\hline
\end{tabular}

Source: Survey Data, 2013

Table 2 shows that a smaller percentage of the respondents ( 20 or 10\%) are between the ages of 15 to 25 years while majority of the respondents who gave their responses fell within the economically active group between the ages of 26 and 45 constituting $30 \%$ and $48 \%$ respectively. The remaining 24 or $12 \%$ are made up 
of respondents between 46 and 56, and above 56 years. This, no doubt, would further justify our results since most of the responses were presumed to be emanating from those with the necessary ICT knowledge and capacity to comment on the benefit of ICT in combating corrupt business activities in Nigeria which helps in achieving the research objectives.

The respondents' gender as displayed in Table 2 indicates that the males (61\%) were more than the females (39\%) which shows that males were more involved in ICT adoption in most businesses organizations in Nigeria. On the respondents' occupation, the table shows that out of the 200 total respondents, 17.5 percent are federal and state employees, while 37.5 percent are local council employees who are deeply involved in government businesses particularly, e-governance initiatives. Manufacturing and service companies constituted 21.5 percent and 15.0 percent, respectively leaving other respondents such as non-governmental organizations, consultants and Individual business men to account for the remaining 8.5 percent. This implies that public and private organizations are more involved in the use of ICT in Nigeria than non-governmental organizations.

Finally, the table shows that the education levels were evenly distributed. Virtually all the respondents were educated, with 53\% having at least Bachelor's degree certificate, 26\% have their Postgraduate Degrees. Diploma holders were about $9 \%$ while others with certificates other than the ones mentioned earlier (at least education up to Post-secondary level and those with HND and Doctoral level of education) were about $12 \%$.These statistics further indicate that most of the respondents had higher education while a relatively small percentage had at least high school education necessary for the respondents to have an informed knowledge on the subject of the study.

\subsection{Test of Hypotheses}

Table 3: Perception on whether ICT adoption does not have significant impact on the reduction of corrupt practices in business activities in Nigeria

\begin{tabular}{lllll}
\hline Category of Response & Frequency & Percentage & $\mathbf{X}^{\mathbf{2}}$ Value & Remark \\
Strongly Agree & 22 & 11 & & \\
Agree & 36 & 18 & 70.35 & Significant \\
Uncertain & 13 & 6.5 & & \\
Disagree & 48 & 24 & & \\
Strongly Disagree & 81 & 40.5 & & \\
Total & $\mathbf{2 0 0}$ & $\mathbf{1 0 0}$ & & \\
\hline
\end{tabular}

Source: Survey Data, 2013

Table 3, which is on perception whether ICT adoption does not have significant impact on the reduction of corrupt practices in business activities in Nigeria, reveals that $22(11 \%)$ and $36(18 \%)$ strongly agreed and agreed, respectively while, $48(24 \%)$ and $81(40.5 \%)$ disagreed and strongly disagreed respectively, while 13 respondents or 6.5 percent were uncertain. This shows that majority of the respondents were of the opinion that ICT adoption have significant impact on the reduction of corrupt business practices in Nigeria. The calculated chi-square value of 70.35 was far greater than the table value of 9.49 at $\mathrm{df}=4$ set at 0.05 level of significance. The null hypothesis was therefore rejected. The result show that ICT adoption has helped in business of governance through reduced government spending \& increased earning, it has also helped in the identification of ghost workers through table payments or integrated payroll and personnel information system (IPPIS), and eliminates other corrupt practices of following files and cheques. This is in line with the research findings of Gasko (2003) and Ahiakwo (2000) who were of the opinion that ICT adoption helps in reducing the cost incurred by government in providing services to citizens and it has reduced the number of in person government contacts which thus, eliminate most of the corrupt practices associated with the process.

Table 4: Perception on whether ICT adoption increases corrupt practices associated with selection and training of employees by most business organizations in Nigeria.

\begin{tabular}{lllll}
\hline Category of Response & Frequency & Percentage & $\mathbf{X}^{2}$ Value & Remark \\
Strongly Agree & 32 & 16 & & \\
Agree & 28 & 14 & & \\
Uncertain & 10 & 5 & 67.40 & Significant \\
Disagree & 52 & 26 & & \\
Strongly Disagree & 78 & 39 & & \\
Total & $\mathbf{2 0 0}$ & $\mathbf{1 0 0}$ & & \\
\hline
\end{tabular}

Source: Survey Data, 2013

Table 4 reveals that $32(16 \%)$ and $28(14 \%)$ respondents strongly agreed and agreed respectively that ICT adoption increases corrupt practices associated with selection and training of employees by most business organizations in Nigeria, while $52(26 \%)$ and 78 (39\%) disagreed and strongly disagreed respectively, 10 or $5 \%$ were uncertain. Since the calculated chi-square value of 67.40 is greater than the table value of $9.49 \mathrm{at} \mathrm{df}=4$ at 0.05 level of significance, we reject the null hypothesis and accept the alternative hypothesis. The result further 
show that ICT helps in the area of e-recruitments and e- examinations in schools, ministries, departments, and parastatals. This is in line with the research findings of Danfulani (2013) and Fatile (2012) who were of the opinion that ICT adoption decreases the level of corrupt practices associated with selection and training of employees by most business organizations in Nigeria as it has drastically reduced the slow, esoteric, and manipulatable processes and excessive involvement of personnel rather than machines.

Table 5: Perception on whether ICT adoption does not enhance transparency and accountability in business of governance in Nigeria

\begin{tabular}{lllll}
\hline Category of Response & Frequency & Percentage & $\mathbf{X}^{\mathbf{2}}$ Value & Remark \\
Strongly Agree & 33 & 16.5 & & \\
Agree & 35 & 17.5 & & \\
Uncertain & 11 & 5.5 & 44.90 & Significant \\
Disagree & 56 & 28 & & \\
Strongly Disagree & 65 & 32.5 & & \\
Total & $\mathbf{2 0 0}$ & $\mathbf{1 0 0}$ & & \\
\hline
\end{tabular}

Source: Survey Data, 2013

Table 5 is on whether ICT adoption does not enhance transparency and accountability in business of governance in Nigeria. Here $33(16.5 \%)$ and $35(17.5 \%)$ strongly agreed and agreed respectively, while 56 $(28 \%)$ and 65 (32.5\%), disagreed and strongly disagreed respectively, 11 or $5.5 \%$ were uncertain. The calculated chi-square value of 44.90 is greater than table value of 9.49 at $\mathrm{df}=4$ This null hypothesis is rejected and the alternative hypothesis accepted. The study further reveals that ICT adoption reduces operations cost, enhances more revenue, facilitate public sector reform and result in greater transparency and accountability in dealing with public funds, thereby leading to better governance and reduce opportunities for corruption. This finding is in line with the position of Heeks (2001) who opined that ICT adoption helps in combating the rampant corrupt business practices in government businesses and Kitaw (2006) who opines that ICT facilitates access to information, freedom of expression, greater equity, efficiency, productivity growth and social inclusion.

Table 6: Perception on whether ICT adoption does not have significant impact on marketing practice in Nigeria

\begin{tabular}{lllll}
\hline Category of Response & Frequency & Percentage & $\mathbf{X}^{\mathbf{2}}$ Value & Remark \\
Strongly Agree & 19 & 9.5 & & \\
Agree & 40 & 20 & & \\
Uncertain & 09 & 4.5 & 86.90 & Significant \\
Disagree & 47 & 23.5 & & \\
Strongly Disagree & 85 & 42.5 & & \\
Total & $\mathbf{2 0 0}$ & $\mathbf{1 0 0}$ & & \\
\hline
\end{tabular}

Source: Survey Data, 2013

Table 6 deals with the Perception on whether ICT adoption does not have significant impact on marketing practice in Nigeria. The table show that $19(9.52 \%)$ and $40(20 \%)$ strongly agreed and agreed respectively, while $47(23.5 \%)$ and $85(42.5 \%)$ disagreed and strongly disagreed respectively, 9 or $4.5 \%$ were uncertain. The calculated chi-square value of 86.90 is far greater than the table value of 9.49 at $\mathrm{df}=4$. This means the null hypothesis is rejected and alternative hypothesis accepted. The study further reveals that ICT significantly contributed to marketing in so many ways, as it has created exciting new ways to learn about and track customers, create products and services tailored to meet customer needs, distribute products more efficiently and effectively, and communicate with customers in large groups or one -to- one using internet or database marketing. This is in line with Kotler (2003) and Akpan (2003) who opined that ICTs such as emarketing, e-commerce, e-business and e-banking provides business organizations with the opportunity to target at individual customers with offers designed to meet their specific needs and buying patterns in the manner that sharp business practices were reduced to the minimal level.

Table 7: Perception on whether ICT adoption does not help in combating fraudulent banking services in Nigeria

\begin{tabular}{lllll}
\hline Category of Response & Frequency & Percentage & $\mathbf{X}^{\mathbf{2}}$ Value & Remark \\
Strongly Agree & 18 & 9 & & \\
Agree & 41 & 20.5 & & \\
Uncertain & 16 & 8 & 51.85 & Significant \\
Disagree & 62 & 31 & & \\
Strongly Disagree & 63 & 31.5 & & \\
Total & $\mathbf{2 0 0}$ & $\mathbf{1 0 0}$ & & \\
\hline
\end{tabular}

Source: Survey Data, 2013

Finally, Table 8 deals with the Perception on whether ICT adoption enhance effective monitoring of individuals and payment of corporate taxes in Nigeria. The table show that $29(14.5 \%)$ and $38(19 \%)$ strongly 
agreed and agreed respectively, while $55(27.5 \%)$ and $73(36.5 \%)$ disagreed and strongly disagreed respectively, 5 or $2.5 \%$ were uncertain. The calculated chi-square value of 66.60 is far greater than the table value of 9.49 at $\mathrm{df}=4$. This means the null hypothesis is rejected and alternative hypothesis accepted.

Table 8: Perception on whether ICT adoption does not enhance effective monitoring of individuals and payment of corporate taxes in Nigeria

\begin{tabular}{lllll}
\hline Category of Response & Frequency & Percentage & $\mathbf{X}^{2}$ Value & Remark \\
Strongly Agree & 29 & 14.5 & & \\
Agree & 38 & 19 & & \\
Uncertain & 5 & 2.5 & 66.60 & Significant \\
Disagree & 55 & 27.5 & & \\
Strongly Disagree & 73 & 36.5 & & \\
Total & $\mathbf{2 0 0}$ & $\mathbf{1 0 0}$ & & \\
\hline
\end{tabular}

Source: Survey Data, 2013

The study further reveals that ICT has helped in averting revenue leakages in many state's boards of internal revenue in the country. For instance, the study found that corrupt ways of declaring profit and loss at the end of each financial year just to evade taxes or get complete tax holidays, as well as recklessness associated with revenue collectors have been drastically reduced. This support the work of Akindele (2005) who is of the opinion that ICT adoption has drastically reduced the fraudulent practices by accounting officers within the civil service in the country.

\subsection{Major Findings}

The major findings based on the analysis of the study revealed that ICT helps in reducing the menace of corrupt practices in business activities in Nigeria. The result show that it helped in business of governance through reduced organizational spending \& increased earning, it has also helped in the identification of ghost workers through table payments or integrated payroll and personnel information system (IPPIS), and eliminates other corrupt practices of following files and cheques. The result further found that ICT adoption helped in reducing the corrupt practices associated with selection and training of employees by most business organizations in Nigeria, particularly in the area of e-recruitments and e-examinations in schools, ministries, departments, and parastatals. The study also found that ICT adoption enhances more revenue, facilitate public sector reform and result in greater transparency and accountability in dealing with public funds, thereby leading to better governance and reduce opportunities for corruption.

Other findings reveals that ICT has significantly contributed to marketing in so many ways, as it has created exciting new ways to learn about and track customers, create products and services tailored to meet customer needs, distribute products more efficiently and communicates with potential customers effectively. It has also helps in combating fraudulent Banking Services in Nigeria as the use of Automatic Teller Machines (ATM) and adoption of recent cashless policy by the Central Bank of Nigeria (CBN) has drastically reduced corrupt cases associated with siphoning of public funds. It also helps the Economic and Financial Crimes Commission (EFCC) in tracking financial fraudsters and international money launderers and results in effective monitoring of individuals and payment of corporate taxes in Nigeria as it averted revenue leakages in many state's boards of internal revenue in the country. For instance, the study found that corrupt ways of declaring profit and loss at the end of each financial year just to evade taxes or get complete tax holidays, as well as recklessness associated with revenue collectors have been drastically reduced.

\subsection{Conclusion}

\section{Conclusion \& Recommendations}

There is no doubt that the introduction of ICT has played significant roles in reshaping business activities in Nigeria as it helps organizations (public and private) in combating corrupt business activities through electronic measures such as e-governance, e-mails, e-payment, e-examination, e-banking, e-marketing, e-commerce and e-business. In spite of the numerous advantages, there are certain limitations which represent barriers to it effective adoption in most business organizations in the country. ICTs such as Internet connectivity, GSM system, computer, and online tools for effective information and communication service are either grossly inadequate or lacking completely in some areas within the country. The study concludes that; organizations that embrace the powerful force stand to reap immense benefit as it is the means by which they can be effective and efficient and thus, remains successful in the competitive environment.

\subsection{Recommendations}

In view of the above foregoing, the following recommendations are made: 
1. Business organizations in Nigeria (public \& private) should ensure adequate provision of ICT infrastructure such as access to computers and capacity to connect to the internet globally.

2. Federal government should ensure that there is massive involvement of local communities in the ICT derive in the country.

3. Mobile Service providers in the country should upgrade their facilities to ensure quality network services across the country, as doing so will help the rapid growth in ICT activities in the country.

4. Security agencies should strengthen their collaborative efforts towards addressing the myriad of problems of equipment vandalism, facing the ICT sector as a result of crime, violence, insurgency or communal conflicts in the country.

5. Adequate laws on cybercrimes in Nigeria should be strengthen to help in the fight against corruption particularly, as it affect ICT related crimes in the country.

6. Aggressive sensitization campaigns through workshops and seminars should be carried out from time to time to sensitize public servants and employees of private sector organizations on the importance of ICT to the effective functioning of their various organizations and their day- to- day life.

\section{References}

[1] Danfulani, "E-Governance: A Weapon for the Fight against Corruption in Nigeria, available online at www.cnknigeria.com, 2013

[2] H. Margetts, (2005). "Electronic Goverment: A Revolution in Public Administration" in B. G. Peters, and J. Pierre, (Ed.), Handbook of Public Administration, (London: Sage Publications, 2005)

[3] M. Gasco, "New Technologies and Institutional change in Public Administration", Social Science Computer Review, 21(1), 2003

[4] P. Kotler, "Marketing Management" (Pearson Education, Singapore, 2003).

[5] S. B. Adewale, "The crowding-out effects of corruption in Nigeria: An empirical study", E3 Journal of Business Management and Economics, 2(2), 2011,059-068.

[6] O. O. Monday, Information and Communication Technology (ICT) in Local Government Administration: The Case of Oshimili North Local Government Area of Delta State, Delta State University, Abraka, Nigeria, 2013

[7] N. Bature, "Business Communication: An Introductory Text" (Joyce Publishers, Kaduna, 2007).

[8] H. Ahmed, et al, Measuring the impact of ICT on women in Bangladesh, Available: http://iec.cugh.Edu.cn/worldcomp, 2006

[9] B. Idowu, E. Ogunbodede, and B. Idewo, Information and Communication technology in Nigeria: The health sector experience. Journal of information Technology Impact 3(2), 2003, 69-76.

[10] C. O. Ahiakwo, The role of Internet connectivity in Nigeria, Available: http://www.isocnig.org.ng/conferencepaper/paper17.htm, 2000

[11] L. Ngouo, Responsibility and Transparency in Organization in Cameroon (Makandala, African Public Administration Zimbabwe APPS Books, 2000).

[12] S. T. Akindele, "A Critical Analysis of Corruption and its Problems in Nigeria", Anthropologist. 7(1), 2005, 7-18

[13] P. O. Osunyikanmi, "Development Implication of Nigeria's Economic Crisis", Journal of Development Perspective, 2(1), 2007, 3459.

[14] P. F. Drucker, The practice of Management (New York: Harper, Row Publishers, 1973)

[15] Z. Fang, "E-governance in Digital Era: Concept, Practice and Development, International Journal of the Computer, the Internet and Management, 10(2), 2002.

[16] G. Hu, W. Pan, M. Lu, and J. Wang, "The widely shared definition of e-Government: An Exploratory Study, The Electronic Library, 2009, 27.

[17] M. Yildiz, "E-governance Research: Reviewing the Literature, Limitations, and Ways Forward". Government Information Quarterly, 2004, 24.

[18] M. J. Moon, "The Evolution of E-governance Among Municipalities: Rhetoric or Reality”, Public Administration Review, 62(4), 2002

[19] N. United, United Nations e-governance Survey 2008 - From e-governance to Connected Governance, Department of Economic and Social Affairs, Division for Public Administration and Development Management, New York, 2008

[20] P. Kotler and K.L. Keller, Marketing Management 12e, (New Jersey, prentice hall, 2006).

[21] J. O. Fatile, Electronic Governance: Myth or Opportunity for Nigerian Public Administration, International Journal of Academic Research in Business and Social Sciences, Vol. 2, No. 9, 2012, 2222-6990

[22] R. Heeks, "Understanding e-governance for Development", i-Government Working Paper Series, Paper No. 11. University of Manchester, Institute of Development Policy and Management, 2001

[23] Y. Kitaw, E-governance in Africa: Prospects, challenges and practices, Lausanne: Division of the Telecommunication Development Bureau of the International Telecommunication Union (ITU), 2006

[24] B. Akpan, Marketing Strategy: The Basic Concept (Zaria, Dada Press, 2003). 